\title{
DOES ENTREPRENEURSHIP EDUCATION HAVE IMPACT ON OPENING AND MAINTAINING A GARMENT BUSINESS STRATEGY?
}

\author{
Farij Ibadil Maula ${ }^{1}$, Ludi Wishnu Wardana ${ }^{2}$, Agus Wibowo ${ }^{3}$ \\ Universitas Negeri Malang ${ }^{1,2}$, Universitas Negeri Jakarta
}

\begin{abstract}
This article aims to analyse the extent of the role of Business Education in upgrading to improve and enhance clothing convection businesses. This article uses descriptive qualitative methods. There were eight sampling participants in the study, including owners and participants of clothing convection businesses. Data analysis was carried out through observation, documentation, and in-depth interviews with participants. The results showed that Business Education did not significantly affect businessmen to open a garment business. The work environment and experience including the educational background of the owners, which varied from elementary school graduate to undergraduate, influenced them to open a garment business Businessmen open garment business because they follow trends, family offspring, continuing friends' businesses, and their great passion. In the strategy of maintaining a garment business, businessmen need Business Education. It is proven by the fact that these owners often participate in screen printing and sewing seminar workshops, read business books, and get business education through field discussions.
\end{abstract}

Keywords: entrepreneurial intention, business education, business strategy

\section{INTRODUCTION}

The phenomenon of low interest and motivation of young people to become entrepreneurs has become a serious thought by various parties. There are psychological factors that shape people's negative attitudes that make them less interested in the entrepreneurial profession-aggressiveness, competitiveness, selfishness, dishonesty, miserly, unstable source of income, and so on. Entrepreneurship has become a popular and urgent study topic for researchers in developed and developing countries. Various attempts were made to foster an entrepreneurial spirit, especially by changing the mind-set that had only been interested as job seekers after finishing school or college. This is a challenge for schools and colleges as

*Corresponding Author.

e-mail: farijmaula@gmail.com

https://doi.org/10.37715/jee.v8i2.1124 graduates producing institutions. Past researches conclude that the more entrepreneurs in a country, the prosperity of its people will be quickly achieved (Obschonka, 2010; Lee, 2011).

Furthermore, the results of several studies (Rowley et al., 2011; Shane \& Venkataraman, 2000) state that entrepreneurial characteristics consist of job creation, innovation, and creativity, high employment, positive social development and economic growth $\mathrm{Ni}$ and $\mathrm{Ye}$ (2018) also agree with the statements of several studies above. They state that motivation, innovation, and creativity as well as corporate knowledge, play a role in which entrepreneurship education influences entrepreneurial intentions, and represents two types of human entrepreneurial knowledge-entrepreneurship and entrepreneurial competence. 
Farij Ibadil Maula, Ludi Wishnu Wardana, Agus Wibowo / Does Entrepreneurship Education have Impact on Opening and Maintaining a Garment Business Strategy? / JEE, Vol. 7, No. 2, September 2019, pp 81-88

Country becomes prosperous if a country's entrepreneur reaches two percent of the total population. Entrepreneurship education can shape the mind-set, attitudes, and behaviors of being a true entrepreneur so that it leads to choosing entrepreneurship as a career choice. The statement was in line with the results of research by Lestari and Wijaya (2012) that entrepreneurship education has a significant effect on entrepreneurial intentions. Entrepreneurial intentions are also reinforced by gender demographic variables, work experience, and parents' work. Entrepreneurship education is a capital investment that not only provides a theoretical foundation for the concept of entrepreneurship, but also shapes the attitudes, behaviour, and mind-set of an entrepreneur.

The more developed a country, the more educated and less unemployed the people are. Then, understanding the entrepreneurial world is increasingly important. Development will be more successful if it is supported by entrepreneurs who can create jobs because the government's ability is very limited. Wibowo (2017) states that entrepreneurship education is an effective instrument for internalizing perceptions, self-efficacy, intentions, and entrepreneurial competencies. Furthermore, Karimi et al. (2016) states that entrepreneurship is basically a deliberate and planned behaviour that can improve economic efficiency, innovation to the market, create new jobs, and improve the quality of work. Thus, entrepreneurship education is a pattern that is used as a basic guideline in the form of global policy through stages that are directed to carry out ideal interactions that are planned and organized in the mechanism of education management and contain the design factors of activity-learning entrepreneurship.

Entrepreneurship education is a shared responsibility between family, community and gov- ernment. Therefore education lasts for life and is carried out within the family, school and community. One important government program at the university level is the Development of Student Entrepreneurship Programs (known as PMW). It is supported by Saptono et al. (2019) who state that the Indonesian government through the Ministry of Research and Technology (Kemenristekdikti) has instructed entrepreneurship training programs on campuses, ranging from materials on entrepreneurial capacity building to entrepreneurship training through the national entrepreneurship movement for students, farmers, and strategic groups. The entrepreneurship program was initiated by higher education through the Directorate General of Higher Education since July 2009. This program provides capital for students who have a business or business plan. Mulyani et al. (2013) emphasize that the experience of entrepreneurship education in school, family, and community as well as vocational skills together had a positive effect on entrepreneurial motivation, in the hope that emerging entrepreneurs who were successful from an early age would be an inspiration for other students to learn and try as much as possible for the progress of the nation.

To become a clothing entrepreneur, a person does not need huge capital because the main capital to become a clothing entrepreneur is skill, strong determination, sincerity, high creativity and innovative. Creativity has long been identified as an important component of entrepreneurship because entrepreneurs must be able to recognize opportunities, generate ideas, and innovate (Saptono et al., 2019). This opportunity was later sought to be fulfilled by the convection entrepreneurs in Malang that were the subject of this study: four clothing convection businesses. Based on the background 
Farij Ibadil Maula, Ludi Wishnu Wardana, Agus Wibowo / Does Entrepreneurship Education have Impact on Opening and Maintaining a Garment Business Strategy? / JEE, Vol. 7, No. 2, September 2019, pp 81-88

Table 1 Participants

\begin{tabular}{ccll}
\hline No. & Code & \multicolumn{1}{c}{ Participants } & \multicolumn{1}{c}{ Name } \\
\hline 1 & KP 1 & Key Participant 1 & Owner of Thre3-G Clothing Printing: Brian \\
\hline 2 & KP 2 & Key Participant 2 & Owner of Defraoi Screen Printing: Trendra Defra \\
\hline 3 & KP 3 & Key Participant 3 & Owner of Brigatelion: Rian Pratama \\
\hline 4 & KP 4 & Key Participant 4 & Owner of Fly\&Fun: Bahrul Ulum \\
\hline 5 & AP 1 & Additional Participant 1 & Employee of Thre3-G Clothing Printing \\
\hline 6 & AP 2 & Additional Participant 2 & Employee of Defraoi Screen Printing \\
\hline 7 & AP 3 & Additional Participant 3 & Employee of Brigatelion \\
\hline 8 & AP 4 & Additional Participant 4 & Employee of Fly\&Fun \\
\hline & & &
\end{tabular}

above, the purpose of this study is to find out the factors that influence the opening and maintaining of garment businesses.

\section{METHOD}

This research is qualitative approach. The research data was taken through primary data sources data obtained directly through brief observation in the work environment of Thre3G Clothing Printing, Defraoi Screen Printing, Brigatelion, Fly \& Fun as well as interviews with participants (Table 1).

After conducting the interview, data analysis begins by making a transcript of the results of the interview, by playing back the recording of the interview results, listening carefully, then writing the words that are heard in accordance with what is recorded. After researchers write the results of the interview into the transcript, there are several things that researchers need to do-data reduction, data display, and data conclusion.

To validate the data, several methods were used: checking the correctness of information to the participants, discussing with friends, correction under the supervisors. In discovering the validity of the finding data, researchers used triangulation.

\section{RESULTS AND DISCUSSION}

Based on the results of the study, the factors that influence businessmen in opening a convection business in Malang include the surrounding environment, family, community, and friendship. It can also come from experiences such as having worked in a garment company or working as another convection reseller. In addition, environmental factors and experience factors such as hobbies/passion in drawing through clothing/t-shirts can also influence. First, Rian (20 years old) is a Brigatelion owner which was established in 2014. Rian runs a clothing convection business because he continues the business of his parents who have opened a tailoring business that focused on Muslim fashion. Rian experience cannot be doubted. He worked for 3 years at the Balisurfingsport convection. Secondly, Ulum (19 years old) is the owner of the Fly\&Fun clothing convection which was established in 2016. Ulum still wants to continue his education at the university level in the hope that he can enlarge his business knowl- 
Farij Ibadil Maula, Ludi Wishnu Wardana, Agus Wibowo / Does Entrepreneurship Education have Impact on Opening and Maintaining a Garment Business Strategy? / JEE, Vol. 7, No. 2, September 2019, pp 81-88

edge and business relationships and develop his own business. Starting from a hobby/passion to draw which is then used as a t-shirt/clothing and can sell the results of the image in t-shirts in large numbers, finally he can open his own clothing convection business. Third, Brian (27 years) has a clothing manufacturing business, Three-G Clothing Printing. It has been established since 2012 with the initial owner named Kos who was then re-owned by Brian in 2014. Brian's business experience is beyond doubt. Since high school, he has been in the online game business. When he was in college, he switched to the business of buying and selling cell phones. Finally, Defra (26 years) is the owner of the Defraoi Clothing Convection. He started his business from the experience of being a clothing convection reseller and went on to open his own clothing business.

\section{ENTREPRENEURIAL INTENTION}

Hermawan et al. (2018) concludes that the influence of entrepreneurial culture is not limited to directing and influencing individuals. Culture consists of the environment, family, and community institutions that affect the whole individual-if the transformed patterns are considered to be the same value. Entrepreneurs are activities that go through the process of buying, selling, producing and exchanging goods and services involving people or companies. Business activities generally have the purpose of generating profits for survival and raising enough funds for the implementation of the activities of the businessperson.

Brian, the owner of the Thre3-G Clothing Printing business, has started a business and worked from his teens when he was in high school. He worked in an internet cafe with a business selling online games, electronic cigarette vape, chicken noodle food, buying and selling cell phones, and even being able to buy a clothing business owned by his friend.

"I started working since high school. I also sold when I worked at an internet cafe. In the internet cafe I got online business opportunities: buying and selling goods, gaming applications, and cell phones through online market places such as Bukalapak, Facebook, etc. Until finally I found a cheap cell phone distributor in Batam." (Brian)

Similar to Brian, Rian, the owner of the Brigatelion business, also worked early. When he graduated from elementary school, he went directly to Bali to follow his mother who worked as a tailor in Balisurfingsport. He began to get to know the business of Balisurfingsport. A few years later, Rian and her mother returned to Malang and opened their own convection business.

"Who will accompany my mother if it's not me? I also learned to work and looked for screen printing sewing there."( Rian)

Different from the two, Ulum opened his business because of his hobby/passion in drawing which was applied to T-shirts/clothing and it turned out to be a business opportunity.

"Starting in middle school I liked to draw pictures in books. Then my friend gave a suggestion to try drawing in Corel Draw or Photoshop to be applied on T-shirts/ clothes and then sell it. It turned out that many people were interested in the t-shirts after I tried it." (Ulum)

Defra, the owner of the Defraoi Screen Printing clothing convection business, is an economics scholar who knows and starts a business from an entrepreneurial college assign- 
Farij Ibadil Maula, Ludi Wishnu Wardana, Agus Wibowo / Does Entrepreneurship Education have Impact on Opening and Maintaining a Garment Business Strategy? / JEE, Vol. 7, No. 2, September 2019, pp 81-88

ment. At that time he tried to become a clothing reseller.

"In the past, my campus gave entrepreneurship courses to do business and made the business profit report as the final grade. I got good grades. It was a trigger to continue the business. That was the first time I became a t-shirt reseller." (Defra)

From the results of interviews with key participants above, the statements are in line with the statements of Turker and Sonmez (2009) that saying one factor affecting one's entrepreneurial spirit, other than internal factors, such as talent or traits that are carried from birth heredity, is because it is formed by factors originating from the surrounding environment.

Relevant to the statement above, (Saptono et al., 2019; Türker and Selçuk., 2009; Nanda $\&$ Sorensen, 2009) agree that personal attitudes, perceived behavioural control, and perceived relational support are predictors of entrepreneurial intentions. Relational support refers to the approval and support of family, friends, and others to be involved in entrepreneurial activities. Family and friends are people who have a big influence in choosing individual careers because they are considered as funds providers and role models. The role of friends and role models stands out in influencing the decision to become an entrepreneur. The triggering factors and encouragement for students to try are: (1) small practices in business with friends, (2) the existence of a business team at school that can be invited to work together in entrepreneurship, (3) there is encouragement from parents, their families for entrepreneurship, and (4) experience in entrepreneurship before they enter school.

From a number of participant statements and links to the theory and research findings of the experts, it can be concluded that the factors that influence entrepreneurial interest owned by business actors, apart from internal factors-such as talent or traits that are carried from birth, are due to factors formed by from the surrounding environment. Dominant environment and work experience is greater than business education in influencing opening a business.

\section{ENTREPRENEURSHIP EDUCATION}

Entrepreneurship education is described as a form of education that aims to raise individuals who are able to start new businesses (Sandhu et al., 2012). The relevant previous research results support the statement of the results of a key participant, Brian, who states:

"My last diploma is D2. And now I am trying to finish my Bachelor's degree at ASIA. I get business learning from discussion/sharing with friends/communities. Through business understanding, I explore and I try to open a new business with a different business. The most important thing is to try first. Success or not is not the most important thing. I gained a lot of experience from the process." (Brian)

Rae and Woodier-Harris (2012) view entrepreneurial education as a process of conceptualizing, organizing, and launching business opportunities into potentially high-growth businesses in complex environments, whether stable or unstable. From the above definition, the four key components are management, organization, integration of resources and the results of opportunities. Richardson and Hynes (2008) agree that there is a positive relationship between education and business creation. Entrepreneurship education can shape the mind-set, attitudes, and behaviors of being a true entrepre- 
Farij Ibadil Maula, Ludi Wishnu Wardana, Agus Wibowo / Does Entrepreneurship Education have Impact on

Opening and Maintaining a Garment Business Strategy? / JEE, Vol. 7, No. 2, September 2019, pp 81-88

neur so that it leads to choosing entrepreneurship as a career choice.

Ulum tells about his final education background and has the desire to continue studying. This is stated in the interview transcript as follows:

"Please pray for me to be able to continue studying in the management economics major so that I can develop this business as well. All this time I only attended workshops or sewing/screen printing training." (Ulum)

Rae and Woodier-Harris (2012), in their research, confirm that career development is the main motivator for international studies in the UK. Entrepreneurship can help overcome the cultural tension between the expectations of postgraduate students and their experience in business education in the UK. This is relevant to the statement of Matlay and Hannon (2006) that entrepreneurship education is a structured formal delivery of entrepreneurial competencies.

From the results of in-depth observations and interviews with participant sources as well as the relationship with the theory of the research results of the experts it can be concluded that the varied educational background of the owner is greatly influencing. Business actors open a clothing business because of following trends, family offspring, continuing the business of friends, from passion. Other factors as triggers and drivers are (1) the existence of petty practices in business with friends, (2) the existence of business teams in schools that can be invited to work together in entrepreneurship, (3) there is encouragement from parents, their families to become entrepreneurs, and (4) experience in entrepreneurship.

\section{STRATEGIC BUSINESS}

Teece (2010) states that strategy is an action that will guide the decisions of top management and company resources that make it happen. Strategy is a process that is planned to achieve the company's goals in the long run. The business unit strategy usually emphasizes efforts to improve the competitiveness of the organization in one industry or one industry segment entered by the organization concerned. The statement is in accordance with the statement of a key participant, Brian.

"In maintaining business, I use networking strategies for production. Whereas in terms of marketing, I use segmenting, targeting, positioning with market segment mapping strategies, mapping market areas, open resellers.” (Brian)

Functional level strategies create a framework for functional management such as production and operations, finance, human resources, marketing, and research innovation. "Creativity has long been identified as an important component of entrepreneurship because entrepreneurs must be able to recognize opportunities, generate ideas, and innovate" (Saptono et al., 2019). This is relevant to the results of interviews with Rian \& Ulum.

"I'm an Aremania. I often watch football matches. Therefore, I have an idea for innovation in developing my business unit by creating an Arema T-shirt branding. Thank goodness many people are interested."( Rian)

"I used to just make a clothing branding called Dropshit. Over time, many customers order bulk costume shirts and some order party shirts. Finally, I opened a clothing convection. If there is a fabric stock left, 
Farij Ibadil Maula, Ludi Wishnu Wardana, Agus Wibowo / Does Entrepreneurship Education have Impact on Opening and Maintaining a Garment Business Strategy? / JEE, Vol. 7, No. 2, September 2019, pp 81-88

I change it to plain shirts for solid resale.” (Ulum)

In conducting business development activities, an entrepreneur generally goes through the following stages of business development: having a business idea, filtering out business ideas or concepts, developing a business plan, implementing a business plan, and controlling a business. Prajogo (2016) mentions the business environment in terms of dynamics and competitiveness as contingency factors that influence the effectiveness of various types of innovation strategies in terms of products and processes in providing business performance.

For instance, Defraoi Convection Company is neat in its business portfolio, financial management, and has a Business Plan strategy.

"I implemented a business plan, management and marketing. I got it all during my college assignments. I apply those knowledge all to my clothing business." (Defra)

Thus, it gives management an idea of what the customer wants, how they want it, and how the company can do it to organize to meet needs, get paid for it, and get profit. The nature of strategy is future oriented. The strategy has multifunctional or multidivisional consequences and in its formulation needs to consider internal and external factors facing the company. This is in line with Manu and Sriram (1996) which states that business strategies based on innovation have been developed and analysed focusing on one dimension of innovation.

Based on the results of surveys, in-depth observations and interviews with participant sources as well as linkages with the theory of expert research results, it can be concluded that strategies need to be planned to achieve the target segmentation target in the long term. To maintain a clothing business, businesses need a series of alternative business strategies in a particular industry or market. This serves to focus the business of competition in any particular industry or market.

\section{REFERENCES}

Hermawan, A., Arief, M., \& Rahayu, W. P. (2018). Dimensions of the Javanese culture and the role of Parents in instilling values in creative industry entrepreneurship. International Journal of Engineering \& Technology, 7(2.29), 182-189.

Hynes, B. (1996). Entrepreneurship education and training-introducing entrepreneurship into non-business disciplines. Journal of European Industrial Training, 20(8), 10-17.

Karimi, S., Biemans, H. J. A, Lans, T., Chizari. M., \& Mulder, M. (2016). The impact of entrepreneurship education: A study of Iranian Students' entrepreneurial intentions and opportunity identification. Journal of Small Business Management, 54(1), 187-209.

Lee, L., Wong, P. K., Der Foo, M., \& Leung, A. (2011). Entrepreneurial intentions: The influence of organizational and individual factors. Journal of Business Venturing, 26 (1), 124-136

Lestari, R. B., \& Wijaya, T. (2012). Pengaruh pendidikan kewirausahaan terhadap minat berwirausaha mahasiswa di STIE MDP, STMIK MDP, dan STIE MUSI. Forum Bisnis Dan Kewirausahaan Jurnal Ilmiah STIE MDP, 1(2),112-119.

Manu, F. A., \& Sriram, V. (1996). Innovation, marketing strategy, environment, and per- 
Farij Ibadil Maula, Ludi Wishnu Wardana, Agus Wibowo / Does Entrepreneurship Education have Impact on

Opening and Maintaining a Garment Business Strategy? / JEE, Vol. 7, No. 2, September 2019, pp 81-88

formance. Journal of Business Research, 35(1), 79-91.

Matlay, H., \& Hannon, P. D. (2006). Teaching pigeons to dance: sense and meaning in entrepreneurship education. Education+ Training, 48(5), 296-308.

Mulyani, E. (2011). Model pendidikan kewirausahaan di pendidikan dasar dan menengah. Jurnal Ekonomi dan Pendidikan, 8(1), 27-36.

Nanda, R., \& Sorensen, J. (2009). Workplace Peers and Entrepreneurship (March 10, 2009). Harvard Business School Entrepreneurial Management (No. 08-051). Working Paper.

Ni, H., \& Ye, Y. (2018). Entrepreneurship education matters: exploring secondary vocational school students' entrepreneurial intention in China. Asia-Pacific Education Researcher, 27(5), 409-418.

Obschonka, M., Silbereisen, R. K., \& SchmittRodermund, E. (2010). Entrepreneurial intention as developmental outcome. Journal of Vocational Behavior, 77(1), 63-72.

Prajogo, D. I. (2016). The strategic fit between innovation strategies and business environment in delivering business performance. International Journal of Production Economics, 171, 241-249.

Rae, D., \& Woodier-Harris, (2012). International entrepreneurship education: Postgraduate business student experiences of entrepreneurship education. Education+ Training, 54(8/9), 639-656.
Richardson, I., \& Hynes, B. (2008). Entrepreneurship education: Towards an industry sector approach. Education + Training, 50(3), 188-198.

Rowley, J., Baregheh, A., \& Sambrook, S. (2011). Towards an innovation-type mapping tool. Management Decision, 49(1), 73-86.

Sandhu, N., Hussain, J., \& Matlay, H. (2012). Entrepreneurship education and training needs of family businesses operating in the agricultural sector of India. Education + Training, 54(8/9), 727-743.

Shane, S., \& Venkataraman, S. (2000). The promise of entrepreneurship as a field of research. Academy of management review, 25(1), 217-226.

Saptono, A., Purwana, D., Wibowo, A., Wibowo, S. F., Mukhtar, S., Yanto, H., Utomo., S. H., Kusumajanto, D. D. (2019). Assessing the university students' entrepreneurial intention: entrepreneurial education and creativity. Humanities \& Social Sciences Reviews, 7(1), 505-514.

Teece, D. J. (2010). Business models, business strategy and innovation. Long Range Planning, 43(2-3), 172-194.

Turker, D., \& Sonmez S. S. (2009). Which factors affect entrepreneurial intention of university students?. Journal of European Industrial Training, 33(2), 142-159.

Wibowo, A. (2017). Dampak pendidikan kewirausahaan bagi mahasiswa. Asian Journal of Entrepreneurship and Family Business, 1(1), 1-14. 